\title{
Hubungan Jumlah Trombosit dengan Nilai Hematokrit pada Penderita Demam Berdarah Dengue dengan Manifestasi Perdarahan Spontan di RSUP Dr. M. Djamil Padang
}

\author{
Wardhy Arief Hidayat ${ }^{1}$, Rismawati Yaswir ${ }^{2}$, Arina Widya Murni ${ }^{3}$
}

\begin{abstract}
Abstrak
Demam Berdarah Dengue (DBD) merupakan salah satu masalah kesehatan masyarakat yang utama di Indonesia. Pemeriksaan jumlah trombosit dan nilai hematokrit menjadi indikator diagnosis DBD. Tujuan penelitian ini adalah menentukan hubungan jumlah trombosit dengan nilai hematokrit pada penderita demam berdarah dengue dengan manifestasi perdarahan spontan di RSUP Dr. M. Djamil Padang. Penelitian retrospektif telah dilakukan terhadap 138 pasien DBD di RSUP Dr. M. Djamil Padang periode Januari 2013 - Desember 2013. Data yang diambil dari Instalasi Rekam Medis adalah jumlah trombosit dan nilai hematokrit yang diperiksa dengan menggunakan alat otomatis Pentra-60. Data dianalisis menggunakan uji korelasi Spearman. Hasil dari penelitian ini didapatkan rata-rata jumlah trombosit adalah $49.779 \pm 35.058 \mathrm{sel} / \mathrm{mm}^{3}$, sedangkan rata-rata nilai hematokrit adalah $43,6 \pm 6,4 \%$. Analisis data hubungan jumlah trombosit dan nilai hematokrit didapatkan nilai koefisien korelasi Spearman ( $r$ ) sebesar $-0,047$ dan nilai signifikasi $p>0,05$. Berdasarkan hasil penelitian, disimpulkan bahwa tidak terdapat hubungan yang bermakna antara jumlah trombosit dengan nilai hematokrit.
\end{abstract}

Kata kunci: demam berdarah dengue, jumlah trombosit, nilai hematokrit

\section{Abstract}

Dengue Hemorrhagic Fever (DHF) is a major public health problem in Indonesia. Examination of hematocrit values and platelet counts as indicators of dengue diagnosis. The objective of this study was to determine the relationship between platelet counts and hematocrit levels in patients with dengue hemorrhagic fever. A retrospective study of 138 patients of dengue in the RSUP Dr. M. Djamil Padang period Januari 2013 - Desember 2013. Data was taken from the Installation of Medical Record is the value of hematocrit and platelet, then data were examined using automated tools Pentra-60. Then the data were analyzed using the Spearman correlation test. The results of this study found the average platelet count on admission was $49.779 \pm 35.058 \mathrm{cells} / \mathrm{mm}^{3}$, while the average hematocrit value on admission was $43,6 \pm 6,4 \%$. Data analysis was then performed to find the relationship of hematocrit value of the platelet count on admission, obtained Spearman correlation coefficient ( $r$ ) of $-0,047$ and a significance value of $p>0,05$. Based on the results, it can be concluded that there was no significant correlation between platelet counts and hematocrit levels.

Keywords: dengue hemorrhagic fever, platelet counts, hematocrit levels

Affiliasi penulis: 1. Prodi Profesi dokter FK Unand (Fakultas Kedokteran Universitas Andalas Padang), 2. Bagian Patologi Klinik FK Unand, 3. Bagian Penyakit Dalam FK Unand/RSUP Dr. M.Djamil Padang.

Korespondensi: Wardhy Arief Hidayat, Email: wardhy91@gmail.com Telp: 081371769991

\section{PENDAHULUAN}

Demam berdarah adalah suatu penyakit infeksi yang disebabkan oleh virus dengue dan ditularkan melalui nyamuk. Nyamuk yang dapat menularkan penyakit demam berdarah adalah nyamuk Aedes 
Aegypti dan Aedes Albopictus. ${ }^{1}$ Penyakit ini merupakan penyakit yang timbul di negara-negara tropis, termasuk di Indonesia. ${ }^{2}$

Demam Berdarah Dengue (DBD) menjadi salah satu masalah kesehatan utama pada masyarakat di Indonesia. Jumlah penderita dan luas daerah penyebarannya semakin bertambah seiring dengan meningkatnya mobilitas dan kepadatan penduduk. Di Indonesia Demam Berdarah pertama kali ditemukan di kota Surabaya pada tahun 1968, dimana sebanyak 58 orang terinfeksi dan 24 orang diantaranya meninggal dunia (Angka Kematian (AK): 41,3\%). Dan sejak saat itu, penyakit ini menyebar luas ke seluruh Indonesia. ${ }^{3}$

Demam berdarah dengue di Indonesia merupakan emerging disease dengan insiden yang meningkat dari tahun ke tahun. ${ }^{4}$ Adapun jumlah penderita DBD di Indonesia sepanjang tahun 1999 sebanyak 21.134 orang, tahun 2000 sebanyak 33.443 orang, tahun 2001 sebanyak 45.904 orang, tahun 2002 sebanyak 40.377 orang, dan tahun 2003 sebanyak 50.131 orang. Pada tahun 2000 insiden rate sebesar 15,75 per 100.000 penduduk meningkat pada tahun 2001 sebesar 17,2\% per 100.000 penduduk. Jumlah kasus DBD di Indonesia antara Januari sampai Maret 2004 secara kumulatif yang dilaporkan dan ditangani sebanyak 26.015 kasus, dengan kematian mencapai $389(\mathrm{CFR}=1,53 \%){ }^{5}$

Berdasarkan data dari Dinas Kesehatan Kota Padang tahun 2010, DBD merupakan penyebab kematian terbanyak di Rumah Sakit Kota Padang. Pada awal tahun 2010 jumlah kasus DBD sebanyak 1045 kasus, angka ini turun dibanding tahun 2009 (1586 kasus) dan tahun 2008 (1219 kasus). ${ }^{6}$

Patofisiologi utama yang terjadi pada DBD yaitu peningkatan permeabilitas vaskuler dan hemostasis yang abnormal. Permeabilitas vaskuler yang meningkat mengakibatkan kebocoran plasma, hipovolemia, dan syok. Gangguan hemostasis dapat menimbulkan trombositopenia, sehingga memunculkan menifestasi perdarahan. ${ }^{7}$

Trombosit merupakan sel darah yang berfungsi dalam hemostasis. Sel ini tidak memiliki nukleus dan dihasilkan oleh megakariosit dalam sumsum tulang. ${ }^{8}$ Pada pasien DBD terjadi trombositopenia akibat munculnya antibodi terhadap trombosit karena kompleks antigen-antibodi yang terbentuk. ${ }^{2}$ Nilai hematokrit adalah konsentrasi (dinyatakan dalam persen) eritrosit dalam $100 \mathrm{~mL}$ darah lengkap. Nilai hematokrit akan meningkat (hemokonsentrasi) karena peningkatan kadar sel darah atau penurunan kadar plasma darah, misalnya pada kasus DBD. Sebaliknya nilai hematokrit akan menurun (hemodilusi) karena penurunan seluler darah atau peningkatan kadar plasma darah, seperti pada anemia. ${ }^{9}$

Pemeriksaan darah sangat bermanfaat dalam pemantauan kondisi penderita dan penentuan prognosis. ${ }^{10}$ Berdasarkan kriteria laboratorium WHO, jumlah trombosit yang rendah (trombositopenia) dan kebocoran plasma yang ditandai dengan hemokosentrasi merupakan indikator penting untuk DBD. ${ }^{11}$ Dari penelitian yang dilakukan Schexneider dan Reedy pada tahun 2005, mengungkapkan bahwa jumlah trombosit tidak berkorelasi baik dengan perdarahan. ${ }^{12}$ Berbeda dengan penelitian di Lahore yang dilakukan oleh Khan dan Hussain pada tahun 2009 didapatkan 14,9\% penderita dengue dengan trombositopenia mengalami manifestasi perdarahan. ${ }^{13}$ Penderita dengan manifestasi perdarahan memiliki risiko kematian 3-4 kali lebih besar dibandingkan dengan penderita tanpa manifestasi perdarahan. ${ }^{14}$

\section{METODE}

Jenis penelitian ini adalah analitik retrospektif dengan desain cross-sectional study. Penelitian ini dilakukan di Instalasi Rekam Medik RSUP Dr. M. Djamil Padang pada bulan September 2014 hingga Oktober 2014.

Populasi penelitian adalah seluruh rekam medik pasien Demam Berdarah Dengue (DBD) rawat inap di Bagian Penyakit Dalam RSUP Dr. M. Djamil Padang bulan Januari 2013 sampai Desember 2013. Sampel berjumlah 138 orang yang diambil dengan metode total sampling. Kriteria inklusi adalah catatan rekam medik pasien DBD dewasa yang dilengkapi dengan identitas, keadaan umum pasien, hasil pemeriksaan laboratorium (nilai hematokrit dan jumlah trombosit), pasien berusia $\geq 14$ tahun, dan dengan perdarahan spontan (ptekie spontan, epistaksis, perdarahan gusi, hematemesis, melena, metrorrhagia). Kriteria eksklusi adalah pasien dengan 
infeksi virus lain yang dapat menyebabkan terjadinya trombositopenia, pasien yang dalam riwayat pengobatan mengonsumsi obat-obat yang dapat mendepresi sumsum tulang, dan pasien yang memiliki riwayat penyakit kelainan darah.

Analisis data terdiri dari analisis univariat dan bivariat dengan rumus Spearman. Variabel dependen adalah nilai hematokrit, sedangkan variabel independen adalah jumlah trombosit.

HASIL

Tabel 1. Karakteristik penderita DBD Berdasarkan Jenis Kelamin dan Umur

\begin{tabular}{lcc}
\hline \multicolumn{1}{c}{$\begin{array}{c}\text { Karakteristik Sampel } \\
\text { Penelitian }\end{array}$} & $\mathbf{f}$ & $\%$ \\
\hline $\begin{array}{l}\text { Jenis Kelamin } \\
\text { Laki-laki }\end{array}$ & 81 & 58,7 \\
Perempuan & 57 & 41,3 \\
\hline Umur & & \\
$<20$ tahun & 50 & 36,2 \\
$20-40$ tahun & 69 & 50,0 \\
$>40$ tahun & 19 & 13,8 \\
\hline
\end{tabular}

Tabel 1 memperlihatkan bahwa sebagian besar subjek adalah laki-laki (58,7\%). Setengah dari jumlah subjek penelitian berusia 20 - 40 tahun $(50,0 \%)$.

Tabel 2. Distribusi Jumlah Trombosit Penderita DBD

\begin{tabular}{lcc}
\hline $\begin{array}{c}\text { Jumlah Trombosit } \\
\left(\mathbf{s e l} / \mathbf{m m}^{3}\right)\end{array}$ & $\mathbf{f}$ & $\%$ \\
\hline$<150.000$ & 138 & 100 \\
$150.000-400.000$ & 0 & 0 \\
$>400.000$ & 0 & 0 \\
\hline
\end{tabular}

Tabel 2 memperlihatkan bahwa semua sampel memiliki jumlah trombosit di bawah normal.

Tabel 3. Distribusi nilai hematokrit penderita DBD

\begin{tabular}{lccc}
\hline \multicolumn{1}{c}{$\begin{array}{c}\text { Nilai Hematokrit } \\
\text { (\%) }\end{array}$} & \multicolumn{2}{c}{$\mathbf{f ~ ( \% )}$} & $\begin{array}{c}\text { Jumlah } \\
\text { (\%) }\end{array}$ \\
\cline { 2 - 3 } & $\mathbf{L}$ & $\mathbf{P}$ & \\
\hline Rendah & 10 & 9 & $19(13,7)$ \\
L: <40; P: $<37$ & $(7,2)$ & $(6,5)$ & \\
Normal & 48 & 27 & $75(54,4)$ \\
L: $40-48 ;$ P: $37-43$ & $(34,8)$ & $(19,6)$ & \\
Tinggi & 23 & 21 & $44(31,9))$ \\
L: $>48 ;$ P: $>43$ & $(16,7)$ & $(15,2)$ & \\
\hline
\end{tabular}

Tabel 3 menggambarkan bahwa sebagian besar sampel memiliki nilai hematokrit yang normal, yaitu pada laki-laki (L) sebanyak 48 orang $(34,8 \%)$ dan perempuan $(P)$ sebanyak 27 orang $(19,6 \%)$.

Tabel 4. Hasil analisis hubungan jumlah trombosit dengan nilai hematokrit

\begin{tabular}{|c|c|c|}
\hline Variabel & $\mathbf{r}$ & $p$ \\
\hline Jumlah Trombosit & \multirow[t]{2}{*}{$-0,047$} & \multirow[t]{2}{*}{0,585} \\
\hline Nilai Hematokrit & & \\
\hline
\end{tabular}

Pada Tabel 4 dapat dilihat bahwa hasil uji statistik didapatkan korelasi negatif dan $p>0,05$ yang berarti tidak terdapat hubungan yang bermakna antara jumlah trombosit dengan nilai hematokrit pada pebderita DBD dengan manifestasi perdarahan spontan di RSUP Dr. M. Djamil Padang.

\section{PEMBAHASAN}

Hasil penelitian diperoleh bahwa penderita dengan usia terendah adalah 14 tahun dan usia tertinggi adalah 64 tahun dengan rata-rata usia penderita yaitu 26,4 tahun. Usia terbanyak penderita DBD adalah usia 18 tahun. Selain itu, dari hasil penelitian juga didapatkan frekuensi umur pasien DBD terbanyak adalah kelompok umur 20 - 40 tahun, dan frekuensi terendah adalah pada kelompok umur $>40$ tahun.

Hal ini sesuai dengan penelitian Valentino pada tahun 2012 bahwa berdasarkan usia, penderita DBD terbanyak adalah pada usia 19 tahun. ${ }^{15}$ Selain itu, berdasarkan penelitian Agilatun pada tahun 2007 menyatakan bahwa berdasarkan kelompok usia, yang paling banyak menderita DBD adalah kelompok usia $15-20$ tahun. ${ }^{16}$ Hasil penelitian ini juga didukung oleh pernyataan dari Carribean Epidemiology Centre tahun 2000 yang menyatakan bahwa epidemiologi penderita DBD terbanyak adalah pada anak-anak dan dewasa muda. $^{17}$

Usia adalah salah satu faktor yang mempengaruhi kepekaan terhadap infeksi virus dengue. ${ }^{18}$ Penelitian di Kuba pada tahun 1981 yang dikutip oleh Sutaryo didapatkan bahwa usia mempunyai peranan yang penting untuk timbulnya gejala klinis berupa kebocoran plasma. ${ }^{19}$ Berdasarkan 
karakteristik jenis kelamin, didapatkan bahwa jenis kelamin laki-laki lebih banyak, yaitu berjumlah 81 orang $(58,7 \%)$, sedangkan perempuan berjumlah 57 $(41,3 \%)$. Hal tersebut serupa dengan penelitian lain yang memperlihatkan bahwa penderita laki-laki lebih banyak dibandingkan dengan perempuan seperti yang dilaporkan oleh Hartoyo pada tahun 2008 dengan lakilaki sebanyak 66 orang $(54,6 \%)$ dan perempuan 57 orang $(45,4 \%){ }^{20}$ Menurut penelitian Wibowo et al. pada tahun 2011 bahwa sepanjang tahun 2006 - 2009 terdapat 852 kasus DBD, terdiri dari 443 laki-laki (52\%) dan 409 perempuan (48\%). ${ }^{21}$ Penelitian Runtunuwu pada tahun 2007 memperlihatkan perbandingan jenis kelamin penderita DBD yang tidak berbeda antara laki-laki dan wanita dengan perbandingan $1,1: 1 .^{22}$

\section{Jumlah Trombosit Penderita DBD}

Berdasarkan hasil penelitian ini, secara keseluruhan jumlah trombosit di bawah normal (trombositopenia) sebanyak $100 \%$. Jumlah trombosit terendah adalah $1000 \mathrm{sel} / \mathrm{mm}^{3}$ dan tertinggi sebesar $138.000 \mathrm{sel} / \mathrm{mm}^{3}$. Rata-rata jumlah trombosit pasien pada penelitian ini adalah $49.779 \mathrm{sel} / \mathrm{mm}^{3}$. Pada penelitian ini, rata-rata jumlah trombosit untuk laki-laki adalah $47.723,33 \mathrm{sel} / \mathrm{mm}^{3}$, sedangkan untuk perempuan sebesar $52.701,7 \mathrm{sel} / \mathrm{mm}^{3}$.

Hal ini didukung oleh penelitian Nopianto pada tahun 2012 yang menyatakan bahwa terdapat $77 \%$ pasien DBD yang memiliki jumlah trombosit $<100.000$ $\mathrm{sel} / \mathrm{mm}^{3}{ }^{32}$ Menurut Jurnah et al pada tahun 2011 didapatkan bahwa sebanyak $71,40 \%$ penderita DBD memiliki jumlah trombosit $<100.000 \mathrm{sel} / \mathrm{mm}^{24}$

Penelitian Kelton et al pada tahun 2011 didapatkan jenis kelamin berhubungan dengan perbedaan sensitifitas dalam hal agregasi trombosit antara laki-laki dan perempuan. Selanjutnya disimpulkan bahwa trombosit laki-laki lebih sensitif daripada trombosit perempuan dalam hal agregasi. ${ }^{25}$

\section{Nilai Hematokrit Penderita DBD}

Hasil penelitian didapatkan bahwa $31,9 \%$ penderita DBD mengalami hemokonsentrasi, sedangkan penderita DBD yang memiliki nilai hematokrit normal sebanyak $54,4 \%$. Pada penelitian ini didapatkan nilai hematokrit terendah adalah $14 \%$ dan tertinggi sebesar $57 \%$. Rata-rata nilai hematokrit pada penelitian ini adalah $43,62 \%$.

Nilai hematokrit adalah besarnya volume sel eritrosit di dalam $100 \mathrm{~mm}^{3}$ darah dan dinyatakan dalam persen. ${ }^{26}$ Pada kasus DBD, terjadinya peningkatan nilai hematokrit (hemokonsentrasi) dikarenakan oleh penurunan kadar plasma darah akibat kebocoran vaskuler. Nilai hematokrit akan menurun saat terjadinya hemodilusi, karena penurunan kadar seluler darah atau peningkatan kadar plasma darah, seperti pada anemia. ${ }^{9}$

Penelitian yang dilakukan oleh Pratiwi pada tahun 2011 didapatkan hal yang sama, yaitu dalam penelitiannya hanya $22 \%$ yang memiliki kadar hematokrit di atas normal. ${ }^{27}$ Penelitian oleh Taufik et al Pada tahun 2007 menyatakan bahwa hanya 16\% penderita $\mathrm{DBD}$ yang mengalami peningkatan nilai hematokrit. $^{28}$

Pada penelitian ini banyak pasien DBD yang memiliki nilai hematokrit normal bahkan rendah dan didiagnosis DBD. Parameter kebocoran plasma sebagai diagnosis DBD menurut WHO tidak hanya peningkatan nilai hematokrit saja, namun juga penurunan nilai hematokrit $>20 \%$ setelah mendapat terapi cairan juga menjadi indikator diagnosis. Kelemahan penelitian ini adalah tidak lengkapnya data rekam medis tentang pengobatan sebelum masuk rumah sakit.

Berdasarkan jenis kelamin, terdapat perbedaan nilai normal hematokrit. Pada penelitian ini, nilai tertinggi untuk laki-laki adalah $57 \%$, sedangkan nilai terendah hematokrit adalah $34 \%$. Untuk perempuan, nilai tertinggi adalah $52 \%$, sedangkan nilai terendah hematokrit adalah 14\%. Rata-rata nilai hematokrit untuk laki-laki adalah 45,5\%, sedangkan untuk perempuan sebesar $40,8 \%$.

\section{Hubungan Jumlah Trombosit dengan Nilai Hematokrit pada Pasien DBD}

Uji korelasi Spearman, didapatkan korelasi negatif yang berarti semakin besar nilai suatu variabel, maka nilai variabel lainnya akan semakin kecil atau sebaliknya. Dengan begitu dapat disimpulkan bahwa semakin rendah jumlah trombosit, maka nilai 
hematokrit akan semakin tinggi. Hal ini sejalan berdasarkan penelitian yang dilakukan oleh JACC pada tahun 2002 didapatkan bahwa terdapat korelasi negatif antara nilai hematokrit terhadap jumlah trombosit. ${ }^{29}$ Penelitian lain yang dilakukan oleh Diana pada tahun 2007 didapatkan bahwa pada penderita DBD mengalami trombositopenia dan hemokonsentrasi yang menjadi patokan terhadap kejadian syok. ${ }^{30}$

Pada penelitian ini didapatkan $p=0,585$, sehingga nilai signifikansi $p>0,05$ yang menunjukkan bahwa tidak terdapat korelasi bermakna diantara kedua variabel. Dapat disimpulkan bahwa tidak terdapat hubungan antara nilai hematokrit dengan jumlah trombosit saat masuk rumah sakit pada pasien DBD.

\section{SIMPULAN}

Tidak terdapat hubungan antara jumlah trombosit dengan nilai hematokrit pada penderita demam berdarah dengue dengan manifestasi perdarahan spontan di RSUP Dr. M. Djamil Padang.

\section{DAFTAR PUSTAKA}

1. Ginanjar G. Apa yang dokter anda tidak katakan tentang demam berdarah. Yogyakarta: B-First; 2004.

2. Suhendro N, Chen L, Khie. Demam berdarah dengue. Dalam: Aru S, editor (penyunting). Buku Ajar IImu Penyakit Dalam Jilid III. Edisi ke-5. Jakarta: Interna Publishing; 2009.hlm.2773-79.

3. Kementerian Kesehatan RI. DBD di Indonesia tahun 1968-2009. Buletin Jendela Epidemiologi Demam Berdarah Dengue. 2010;2:1-14.

4. Efendi F, Fachrizal A, Mahendra Tri AS. Studi komparasi perilaku masyarakat dan kondisi lingkungan pada kejadian demam berdarah dengue di daerah KLB dengan non KLB di Surabaya. Jurnal IImiah Mahasiswa Kedokteran Indonesia. 2006;1(2):10-6.

5. Giusman R. Early warning system (EWS) berbasis iklim sebagai upaya mencegah kejadian luar biasa (KLB) demam berdarah dengue di Indonesia. Jurnal IImiah Mahasiswa Kedokteran Indonesia. 2006;1(2):28-33.
6. Dinas Kesehatan Kota Padang. Profil kesehatan kota Padang tahun 2010. Padang: DKK; 2011.

7. Shepherd SM. Dengue fever [serial online] 2007 (diunduh 1 April 2014). Tersedia dari: URL: HYPERLINK http://.www.emedicine.medscape.com.

8. Sloane E. Anatomi dan fisiologi (terjemahan). Jakarta: EGC; 2004.hlm.218-28.

9. Sutedjo AY. Mengenal penyakit melalui hasil pemeriksaan laboratorium. Yogyakarta: Amara Books; 2007.hlm.27-38.

10. Jameel T, Mehmood K, Mujtaba G, Choudhry N, Afzal N, Paul RF. Changing haematological parameters in dengue viral infections. $\mathrm{K}$ Ayub Med Coll Abbottabad. 2012;24(1):124-28.

11. World Health Organization (WHO). Comprehensive guidelines for prevention and control of dengue and dengue haemorrhagic fever. WHO; 2011.

12. Schexneider KI, Reedy EA. Trombocytopenia in dengue fever. Current Hematology Reports. 2005;4(2):145-8.

13. Khan KM, Hussain I. Trends of clinical symptoms and haemotological profile of dengue fever among hospitalized patients at Sir Ganga Ram Hospital, Lahore. [serial online] 2009 (diunduh 30 Maret 2014). Tersedia dari: URL: HYPERLINK http://pimhsonline.com/trends of clinical symptom s and.htm.

14. Ong A, Sandar M, Chen MI, Sin LY. Fatal dengue hemorrhagic fever in adults during a dengue epidemic in Singapore. International Journal of Infectious Disease. 2007;11:263-7.

15. Valentino B. Hubungan antara hasil pemeriksaan darah lengkap dengan derajat klinis infeksi dengue pada pasien dewasa di RSUP Dr. Kariadi Semarang. (skripsi). Semarang: Universitas Diponegoro; 2012.

16. Agilatun F. Hubungan antara jumlah leukosit dengan kejadian syok pada penderita demam berdarah dengue dewasa di RSUP Dr. Kariadi Semarang. (skripsi). Semarang: Universitas Diponegoro; 2007.

17. Carribean Epidemiology Centre. Clinical and laboratory guidelines for dengue fever and dengue haemorrhagic fever/dengue shock syndrome for 
health care providers. Journal of Pan American Health Organization. 2000:1-10.

18. Wichmann O, Hongsiriwon S, Bowonwatanuwong C, Chotivanich, Sukthana, Pukrittayakamee S. Risk factor and clinical features associated with severe dengue infection in adults and children during 2001 epidemic in Chonbiri, Thailand. [serial online] 2004 (diunduh 16 September 2014). Tersedia dari: URL: HYPERLINK http://onlinelibrary. wiley.com/doi/10.1111/j.13653156.2004.01295.x/full.

19. Sutaryo. Perkembangan patogenesis demam berdarah dengue. Dalam: Hadinegoro, Satari HI, editor (penyunting). Demam Berdarah Dengue. Edisi ke-1. Jakarta: Balai Penerbit FKUI; 2004.

20. Hartoyo E. Spektrum klinis demam berdarah dengue pada anak. Sari pediatri. 2008;10(3):14550 .

21. Wibowo K, Mohammad J, Ida SL, Sri M. Pengaruh transfusi trombosit terhadap terjadinya perdarahan masif pada demam berdarah dengue. Sari Pediatri. 2011;12(6):404-8.

22. Runtunuwu AL. Studi perbandingan pengobatan demam berdarah dengue derajat III dan derajat IV. Sari Pediatri. 2007;8(3):42-7.

23. Nopianto $H$. Faktor-faktor yang berpengaruh terhadap lama rawat inap pada pasien demam berdarah dengue di RSUP Dr. Kariadi Semarang (skripsi). Semarang: Universitas Diponegoro; 2012.

24. Jurnah M, Arif D, Bahar M, Burhanuddin. Uji hematologi pasien terduga demam berdarah dengue indikasi rawat inap. Indonesian Journal of
Clinical Pathology and Medical Laboratory. 2011; 17(3):139-42.

25. Kelton JG,Powers P, Julian J, Boland V, Carter CJ, Gent M. Sex related differences in platelet aggregation: influence of the hematocrit. Blood Journal of American Society Hematology. 2011; 56(1):38-41.

26. Hadinegoro SR, Soegijanto S, Wuryadi S, Suroso T. Tatalaksana Demam Berdarah Dengue di Indonesia. Jakarta: Direktorat Jenderal Pemberantasan Penyakit Menular dan Penyehatan Lingkungan; 2006.hlm.1-24.

27. Pratiwi RE. Hubungan kadar trombosit dan hematokrit dengan gejala klinis penderita DBD di rumah sakit umum Dr. Saiful Anwar Malang pada tahun 2007-2010 (skripsi). Semarang: Universitas Brawijaya; 2011.

28. Taufik A, Didit Y, Farid W. Peranan kadar hematokrit, jumlah trombosit, dan serologi IgG-IgM anti DHF dalam memprediksi terjadinya syok pada pasien demam berdarah dengue di Rumah Sakit Islam Siti Hajar Mataram. Jurnal Penyakit Dalam. 2007;8:105-11.

29. J Am Coll Cardiol. Relationship between platelet count and hematocrit. JACC Journals. 2002; 39(6):1072-77.

30. Diana M. Korelasi antara trombositopenia dengan hemokonsentrasi sebagai faktor predisposisi terjadinya syok pada pasien demam berdarah dengue dewasa di RSUP Dr. Kariadi Semarang (skripsi). Semarang: Universitas Diponegoro; 2007. 